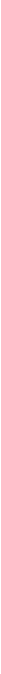

\title{
Gender and Religion in Nigeria: The Role of Northern Nigerian Muslim Women in National Development.
}

\author{
Authors: Usman Al-amin \\ Submitted: $\quad$ 10. November 2018 \\ Published: $\quad$ 22. November 2018 \\ Volume: $\quad 5$ \\ Issue: $\quad 9$ \\ Affiliation: Department of History. University of Maiduguri. Borno State, \\ Nigeria \\ Languages: English \\ Keywords: Gender, Religion, Nigeria, Development \\ Categories: Humanities, Social Sciences and Law \\ DOI: $\quad$ 10.17160/josha.5.9.503
}

\section{Abstract:}

What is the role of the northern Nigerian Muslim women in national development? This is a question for which we do not have a good answer. All that we know is how important women are in marital life as housewives but their role in politics and civil service remain obscure. This is because the literature on Nigeria's national development is relatively silent on the contributions of Muslim women. In northern Nigeria, awareness about the role of Muslim women in development gained momentum in 1985 with the formation of The Federation of Muslim Women's Associations in Nigeria (FOMWAN). Awareness was further enhanced in 1995 as a result of the effective participation of northern Nigerian Muslim women in the International Conference on Women in Beijing, China. The case study is an attempt to analyze the role of Muslim Women in an urban middle-class context in Northern Nigeria.

\section{JOSHA \\ Journal of Science, Humanities and Arts




\title{
Gender and Religion in Nigeria: The Role of Northern Nigerian Muslim Women in National Development
}

\section{Usman Al-amin}

Department of History, University of Maiduguri. Borno State, Nigeria. alaminusman81@gmail.com

\begin{abstract}
What is the role of the northern Nigerian Muslim women in national development? This is a question for which we do not have a good answer. All what we know is how important women are in marital life as housewives but their role in politics and civil service remain obscure. This is because the literature on Nigeria's national development is relatively silent on the contributions of Muslim women. In northern Nigeria, awareness about the role of Muslim women in development gained momentum in the 1985 with the formation of The Federation of Muslim Women's Associations in Nigeria (FOMWAN). ${ }^{1}$ Awareness was further enhanced in 1995 as a result of the effective participation of northern Nigerian Muslim women in the International Conference on Women in Beijing, China. In spite of these efforts, it is appropriate to state that the role of northern Nigerian Muslim women in development has not been sufficiently emphasised. It is against this background; this paper tackles thorny question raised by many scholars regarding the role of Muslim women in nation building in northern Nigeria. The case study is an attempt to analyze the role of Muslim Women in an urban middle-class context in Northern Nigeria. This study is based on my own anthropological fieldwork in the cities of Northern Nigeria. The study concludes that Northern Nigerian Muslim women who are nationally patriotic has the ability, capacity and capability to contribute their quota in Nigeria's development.
\end{abstract}

${ }^{1}$ FOMWAN is a faith-based umbrella organization that links Islamic women's groups in Nigeria and promotes Muslim women's viewpoints on the national stage. 


\subsection{Introduction: A Historical Overview}

Northern Nigerian Muslim women occupy a very significant and decisive place in the social, cultural, economic and political life of Nigeria. ${ }^{2}$ Their importance is evident both in traditional and modern sectors, not only as housewives and mothers in society but also a national role, because of their contribution to the quality of day to day life. Northern Nigeria being predominantly an Islamic society, there are some limitations for women to progress in education and to be considered outside their family roles, expectation and responsibilities. Islam, which was introduced to northern Nigeria in $11^{\text {th }}$ century, had become the religion of all urban dwellers by the turn of the twentieth century. ${ }^{3}$ Muslim women in northern Nigeria constitute about $50 \%$ percent of region`s population and are playing vital role in the social reproduction of the society. ${ }^{4}$ In spite this, the society has not accorded them enabling political, economic, educational and cultural atmosphere to actively participate in national development relative to their men counterparts. This is due to some cultural stereotype, traditional practices and patriarchal societal structure. $^{5}$

However, the discrimination of Muslim women from this region in participation in national development is rooted on precolonial, colonial and post-colonial history. Precolonial Nigerian economy was basically at a subsistence level, and Nigerian women (including Muslim women from northern Nigeria) participated effectively in in their respective families, clans, kingdom, empire in this economy. ${ }^{6}$ In the colonial period, the colonial policies and statutes were clearly sexist and biased against women. This is connected to the fact that the colonial economy was an export oriented one and it seriously undermined the prestige of the traditional occupations of Nigerian women. While it placed women at a great disadvantage, it enhanced the economic status of the British, Lebanese, Syrian and a few male Nigerian merchants. ${ }^{7}$ During this period, education was functional. The curricula emphasized religious instruction and clerical skills for

\footnotetext{
2 Zainab Bukar, (40 years), Maiduguri, interviewed on 06/04/2018.

${ }^{3}$ Salah M. Hassan 1992:1.

${ }^{4}$ Ayesha Imam 1988:178.

${ }^{5}$ Vivian Bakpa 2018:

${ }^{6}$ S. A. Effah Attoe 2002

7 Ibid.
} 
boys and domestic science for girls. ${ }^{8}$ Technological and scientific based education was not encouraged. ${ }^{9}$ The curricula for girls enabled them to become good housewives, rather than income earners. ${ }^{10}$ As regards politics, colonialism affected Nigerian women adversely as they were denied the franchise and very few of them were offered any political or administrative appointments.

Nigerian women began to play very active roles in various aspects of the nation's development and assumed a more critical role in traditional agriculture. In 1979, women constituted 4,9 per cent of agricultural manpower in Nigeria, 1.4 per cent of artisans and craftsmen, and 1.6 per cent of the professional/subprofessional group. It was only in the medical sector that women constituted 84.3 per cent of dieticians and 80.2 per cent of nurses. ${ }^{11}$ The position of women in education in post-colonial Nigeria has not improved much. According to the Population Reference Bureau, in1981, only 6 per cent of adult Nigerian women were literate. By 1979, 72.9 per cent of urban girls and 80.08 per cent of rural girls were not attending school $^{12}$.

This on-going development of the discrimination and contribution of Northern Nigerian Muslim women national development have never been systematically studied. It is against this background that this study has been motivated. The study argues that culture and mentality of inferiority complex are the crucial factors that marginalized these women not religion as erroneously believed by many. The study, finally, submitted that if northern Nigerian Muslim women in their continuous attempt to participate in Nigeria's development, were given chance by the men, they will contribute their quota in all ramifications such as politics, economic, educational, social, cultural etc.

\subsection{Statement of the Problem}

The unending rivalry for all the good things of life between the modern man and modern women has made it the more difficult to appreciate the fact that the woman more than the man

\footnotetext{
8 Ibid.

${ }^{9}$ Ibid.

10 Ibid.

11 Ibid.

12 Ibid.
} 
has a lot of role to play in the survival of Nigeria and its development. This study is concerned with the role of Northern Nigerian Muslim women in the national development. In northern Nigeria, the contributions to the national development, in which both sexes participate, assert the equality of the sexes. Participation for everyone is said to be subject to the same requirement and credential imperatives; women and men have equal access to the different roles that constitute the structure of politics and government. ${ }^{13}$ But the assumption of sexual equality in national development is in complete contradiction to gender relationships as they are defined social and practice in northern Nigeria. Northern Nigeria is a patrilineal society provides a clear example of male domination legitimized by the reduction of women to their sexuality alone. There is no political and social arena in which women are not forced into a class of inferior status and in which both sexes can enter into competitive relationships without bias against the women. ${ }^{14}$ This on-going development of the discrimination of Northern Nigerian Muslim women participation in northern development has not been systematically studied. This study seeks to fill this gap.

\subsection{Research Objectives}

This paper deals with primarily with the role of Northern Nigerian Muslim women in national development. The specific objectives of the paper are to:

i. examine the nature of relationship between Northern Nigerian Muslim women and national development.

ii. investigate the historical and contemporary factors that led to the participation of Northern Nigerian Muslim women in national development.

iii. explain the major roles of Northern Nigerian Muslim women in national development.

iv. provide recommendations which will help in overcoming the constraints that prevented the participation of Northern Nigerian Muslim women in national development.

\subsection{Research Questions}

The considerable confusion in understanding the role of Muslim women in political circles in northern Nigeria and elsewhere in Nigeria has generated many questions. in interesting

\footnotetext{
${ }^{13}$ Zainab Bukar, (40 years), Maiduguri, interviewed on 06/04/2018.

${ }^{14}$ Nana Auwalu, (34 years), Nguru, interviewed on 04/04/2018
} 
the context of Islamic intellectual history. This study is an attempt to provide answers to the following relevant questions:

i. Is there any nexus between Muslim women and national development?

ii. Why knowledgeable Muslim women were not generally recognized as capable of holding an office, and why it was often thought that they have role to play in the political domain?

iii. What are the motivating factors that led to the participation of Muslim women in national development?

iv. What were the major roles of Muslim women in national development?

v. What recommendations would help in overcoming the constraints that prevented the participation of Muslim women in national development?

\subsection{Research Assumptions}

This study is an attempt to test the assumption that Northern Nigerian Muslim women who happened to be custodian of society the ability, capacity and capability to contribute to national development. Muslim women in northern Nigeria as a case study have been used to illustrate this assumption. In other words, it hopes to validate the preposition that the Muslim women in northern Nigeria national development, which this study examines and discusses, if they are given chance, they will contribute to Nigeria's development.

\subsection{Previous Studies}

There is a current dearth of sources on the role of northern Nigerian Muslim women in the national development. It is pertinent to mention however some readily available titles in circulation. Hiskett, 1960, Hogben and Kirk-Green 1966, Last 1967, Palmer 1936, H. F. C. Smith 1975; M. G. Smith 1960, 1978. Despite the existence of these literatures, Barbara (1987) in her book, Muslim Hausa Women in Nigeria: Tradition and Change stated that any attempt at reconstruction of the public role of women in earlier periods of Nigerian history is difficult, although some indication of roles assumed by women who were part of the ruling classes may be 
glimpsed from the secondary historical information. ${ }^{15}$ This work is a timely response to that call. This work has thrown some light on several relatively unknown roles of women in the national development. Cohen also give some indication of the important role played by women in times past.

\subsection{Religion, Culture and Gender in Northern Nigeria}

Women's inequitable gender relations, their culture and religion in northern Nigeria are interconnected. ${ }^{16}$ Of the crucial components that constitute human conduct in the region is gender which is a product of both religion and society, where they play a dominant role. The role religion plays in gender relations has often been ambivalent and it is also culture that have molded women's and men's roles and sphere of influence in the society ${ }^{17}$. According to King "women's position in religion is often a reflexion, however oblique, of women's status in society" 18 However, in Nigeria and culture tended to marginalize women by relegating them to the periphery of history and assigning them subordinate positions. Nigeria has performed poorly in terms of gender equality. According to the 2012 Gender in Nigeria Report, data suggest that Nigeria ranks 118 out of 134 countries in the Gender Equality Index. ${ }^{19}$ At every educational level woman earn less than their male counterparts and in some cases men with less education earn more than better educated female peers. ${ }^{20}$ Also, Nigerian girls drop-out of school earlier than their male counterparts. ${ }^{21}$ Evidence further shows that more than two thirds of 15-19-year-old girls in Northern Nigeria are unable to read a sentence. ${ }^{22}$ These artificial factors may enhance or hinder the development efforts and equality for women in all ramifications because men still dominate women resulting in widespread discrimination against women and girls. ${ }^{23}$ These impacts of unequal power relations and discrimination is often felt most severely when material

\footnotetext{
${ }^{15}$ Barbara J. Callaway 1987:3.

${ }^{16}$ Zainab Bukar, (40 years), Maiduguri, interviewed on 06/04/2018.

${ }^{17}$ Christopher Amherst Byuma Zigira 2003:1.

${ }^{18}$ King U 1995:15.

${ }^{19}$ Uzoma Aja-Okorie 2013:274.

20 Ibid.

21 Ibid.

22 Ibid.

23 Ibid.
} 
poverty exists, as this increases vulnerability. ${ }^{24}$ Inequality in the Nigerian society inevitably has an impact on the provision and content of education, as well as on the ability of girls to enter, and remain in, school. ${ }^{25}$ However, the gender disparity is intensified by the powerful economic and social rationale for investing in the education of sons rather than daughters, as daughters are perceived to be less valuable once educated, and less likely to abide by the will of the father, brother or husband. ${ }^{26}$

Women have always been the biggest "consumer" of religion, but on the whole have been badly served, disparaged and oppressed by religions themselves. In most organized religions to be born a woman is valued as (sic) punishment, either for misdeeds in a previous life or for the sin of the first woman ${ }^{27}$

It is believed that religion permeated all aspect of life to such an extent that it was difficult to separate the two. Though some scholars argued it was life that permeated all spheres of religion. Today, at all level of society, women are assuming more responsibility for themselves and their families, particularly as their menfolk are often absent, either working or seeking employment elsewhere in the northern Nigeria and the southern Nigeria. In the process, women are finding new sources of strength and support, both within themselves and from other women. The private, women's world of northern Nigeria is becoming more public but without losing the values and order of Muslim culture non-which it is firmly based. It must be stressed from the outset that such changes and increased opportunities are relative to that culture and society: a Muslim society with Islamic ideals, both traditional and modern, popular and formal, which are quietly pervasive and openly adhered to. ${ }^{28}$ Women everywhere are becoming more independent and confident, even though the most the cost is sometimes great. Such characteristics are not without precedents, as the following pages show, but they have never been so evident before. The liberal feminist perspective on the aspiration of Nigerian women and the constructivist theory on international gender-regime have become serious concern to the gender.

\footnotetext{
24 Ibid.

25 Ibid.

${ }^{26}$ Uzoma Aja-Okorie 2013:275.

${ }^{27}$ King Ursula 1995.

${ }^{28}$ Hajiya Hauwa, (41years), Nguru, interviewed on 24/03/2018.
} 
The current status of Nigerian women in politics and the efforts made toward achieving active political participation appear not to be commensurate. ${ }^{29}$

The leaders, scholars and parents in northern Nigeria must commit to eradicating gender inequalities; mainstream gender; create a standing committee for gender affairs. ${ }^{30}$ Policy-makers must work with women to improve their positions and accelerate national development. ${ }^{31} \mathrm{~A}$ comprehensive approach must be taken to remove the social, economic and legal constraints on women. ${ }^{32}$ New administrative arrangements must be found to support their education and make it more consistent with their needs. ${ }^{33}$ Gender biases must be considered to improve women's ability to take advantage of incentive. ${ }^{34}$

\subsection{Nexus Between Muslim Women and National Development}

Lawal and Oluwatoyin (2011) defined national development as the overall development or a collective socio-economic, political as well as religious advancement of a country or nation. ${ }^{35}$ However, in this paper, national development will refer to the ability of a country or countries to improve the social welfare of the people, by providing social amenities like quality education, potable water, transportation, infrastructure, medical care, etc. National development aims at continuous improvement of the nation and its social systems, towards a better and more human standard of living which cannot be achieved without the role of woman. However, it is universally truth that women as individuals are having a determining part in bringing up exalted human beings, society and a nation at large. Women as the basic managers of the family play an essential role in the human and national development. Involvement of women in politics affords them the opportunity to be at these policy/decisions making bodies. Women at these levels, use their professional knowledge to contribute their quota to important national development projects.

\footnotetext{
${ }^{29}$ Ibid.

${ }^{30}$ Fapohunda M. Tinuke 2012: 14.

31 Ibid.

32 Ibid.

33 Ibid.

34 Ibid.

${ }^{35}$ Lawal, T. and Oluwatoyin, A. 2011:241.
} 
Similarly, women in politics contribute to the enhancement of the welfare of other women thereby motivating them to higher productivity for national development.

Much has been written on the relationship between women and national development. Consequently, almost all their findings indicate that women have veritable role to play in national development. The degree to which women affect national development also depends on status and freedom. In many societies across the world, there are some limitations for women to play a role in national development and to be considered outside their family roles, expectation and responsibilities. Reinarz (2002) argues that balancing work and family is a major hurdle for working women. ${ }^{36}$ Hence, family responsibilities influence the careers and education choices of women who mostly have disproportionate work in care if children and the home. Many experiences showed that women have a very complex web of multi-roles and multi-tasks to conduct at different times in a bid to fulfill their own quota to national development. These roles have been theoretically characterized as reproductive, productive and community roles. It is in view of this that the true meaning of National development cannot be realized without mutual material and spiritual contribution of women. The personal status and religion of human and their effective role in various dimension including their role at home, in the society limitation regarding their activity and finally, helping the process of national development.

\subsection{The Missing Links of Between Northern Muslim Women and National Development}

Women's social role in Nigeria differs according to religious and geographic factors. Northern Nigeria being predominantly an Islamic society. The role of Muslim woman is clearly defined in Islam. ${ }^{37}$ Her primary role is the upbringing of her children and being a dutiful wife. Islam also permits the woman to exercise the vote, engage in politics, to take up employment and even run her own business. In the northern Nigeria, there are a wide of missing links which effectively prevented Muslim women to play a role in national development. So, to understand inhibitions on women and development and progress, it is worthwhile addressing the myths about the role of the Role of Northern Muslim Women in Nigeria's Development. Some of these the missing links in northern Nigeria identified are:

\footnotetext{
${ }^{36}$ Reinarz (2002) as cited in Uzoma Aja-Okorie 2013:274.

${ }^{37}$ Zainab Bukar, (40 years), Maiduguri, interviewed on 06/04/2018.
} 
1. Welfare: Here the welfare of women is considered e.g. nourishment, supply of adequate nutrition and family income.

2. Access to sources: In this orb, women have equal rights with men to benefit from fairly resources to a larger scale from national cake.

3. Awareness: In this stage, after given qualitative education to women, women understand the structural inequality in the process of development and that the problems facing them do not result from their own inability and personal shortcomings but are the outcome of a social system in which unjust discrimination was acceptable.

4. Participation: This demands participation of women in the whole process of development i.e. evaluating the needs problems, planning, management and implementation of projects.

5. Control: This aims at the increased participation of women up to and including the level of decision-making, women shall have control over production equal access to resources and equitable distribution of profits.

6. Development of Women's Affairs: Women's affairs cannot be developed unless women can participate in cultural, spiritual, political and economic activities of a nation.

7. Taking religious teaching into consideration, the social status and role of women is determined according to the principle of submission to Almighty Allah.

8. Equalization of the background for playing a development. This is a strategic principle more realistic logical and humanistic than the principle of equalization of sexuality.

9. The basic problem in the current development concerning women is more from normative recommended patterns (ideal status for women) that form the principle of equalization of the background for playing the developmental role.

1O. Proportionate Sexuality: This is another principle in the equalization of sexuality. ${ }^{38}$

These are some of the factors for enabling northern Nigerian Muslim women to play a role in national development, men are also expected to assist them in removing these obstacles and paving the way to their goals. For a more elaborate discussion on the role of Muslim women

\footnotetext{
38 Yani Garba, (28 years), Maiduguri, interviewed on 23/03/2018.
} 
in national development in Nigeria, we intend to discuss the subject from two angles political, economic, intellectual, social and cultural angles.

\subsection{The Role of Northern Muslim Women in Nigeria's Development}

Several decades ago, one of the most challenging issues in northern Nigeria is that of the role of Muslim women in national development. ${ }^{39}$ Their role in national development had been become a point of controversy, especially in terms of their rights and demands for equality. Despite the numerical strength of Muslim women in northern Nigeria, their impact has been rarely felt in politics, civil service, economic sector etc. A lot of factors can be identified as militating against the effective participation of northern Nigerian Muslim women in national development. The women face greater vulnerabilities in the labor market because of their relative lack of education and training. Education for women advances their economic empowerment, and also promotes development more generally. Lack of access to formal education and training is a key barrier to women's employment and advancement in society. The ongoing economic crises and the gulf between job creation and the growth in the numbers of job seekers have worsened the employment situation for women and men alike. The solution to these factors will equip them to grasp again their early role in Islam of involvement and even leadership in the political, social, spiritual, economic, cultural or intellectual life of Nigeria.

\subsubsection{The Political Role of Northern Muslim Women in Nigeria's Development}

The political role of Muslim women in national development involves political behavior (participation or non-participation in politics) participation a refers, models of political conduct and public opinion. In Islamic history, women at time of the Prophet were not isolated from society or politics. Women were known to have gone out with men in Jihad for various services. We are also aware that Aisha, the Prophet's wife, took part in politics and even waged a war when she took sides with Mu'awiyya in the crisis that rose after the death of Othman (RA). ${ }^{40}$ Zainab, the daughter of the Prophet, also participated in Jihad and the speeches she made indicated that she believed she was fighting a Jihad in society. ${ }^{41}$

\footnotetext{
${ }^{39}$ Umma Abdullahi, (23 years), Nguru, interviewed on 04/04/2018.

40 Zainab Bukar, (40 years), Maiduguri, interviewed on 06/04/2018.

${ }^{41}$ Umma Abdullahi, (23 years), Nguru, interviewed on 04/04/2018.
} 
The northern Nigerian scenario today presents an interesting experience on the changing role of the woman. The history of women participation in politics in northern Nigeria for instance dates to the pre-colonial era. Women at this period played their influential roles within their respective communities. During the pre-colonial Hausa society, for instance, women held titles such as Magajiya, Iya and Mardanni. ${ }^{42}$ There was, for instance, Queen Amina of Zazzau, in what is today northern Nigeria, rose to power as an adolescent when her father was ruler. She regularly participated in military expeditions. In 1576 she came to the throne, following her father's successor. She used her military to expertise to extend the boundaries of her realm to the Niger River, incorporating the city states of Kano and Katsina. The people of Kano and Katsina paid tributes to her. She turned Zaria into a very prominent commercial centre. She built a high wall around Zaria to protect the city from invasion and extended the boundaries of her territory beyond Bauchi. She brought wealth to her people by extending the long-distance trade routes, and she is credited with introducing kola nuts, an important trade and social item in many West African communities. ${ }^{43}$

However, in precolonial Borno, for instance, women played active parts in the administration of the state. They held very important offices in the royal family, including the offices of the Magira (the Queen mother) and the Gumsu (the first wife of the Mai or King). ${ }^{44}$ The role of women in northern Nigerian Muslim women in politics has not been reflected sufficiently, in terms of appointments to policymaking posts. Despite massive support given to various political parties by women, women organizations, market women movements etc., until recently, very few women benefited from political patronage. ${ }^{45}$ As regards politics, colonialism affected Nigerian women adversely as they were denied the franchise and very few of them were offered any political or administrative appointments. In northern Nigeria, however, women were still denied the franchise even after independence. As a result, prominent female politicians like

\footnotetext{
42 Otu Ekpenyong 2015:2.

${ }^{43}$ Kathleen Sheldon 2005: Xxxiii.

${ }^{44}$ S. A. Effah Attoe 2002.

45 Ibid.
} 
Hajiya Gambo Sawaba in the northern Nigeria could not vote and be voted for. ${ }^{46}$ It was only in 1979 that women in north ern Nigeria were given the franchise, following the return to civilian politics. In the early 1990s, one woman was appointed Deputy Governor. ${ }^{47}$ This was Mrs. Pamela Sadauki of Kaduna State. During the same period, very few women emerged as councilors. ${ }^{48}$ Amongst the members of the Transitional Council appointed by President Babangida in January 1993, only one woman form northern Nigeria was appointed, Mrs. Laraba Dagash. ${ }^{49}$ During the military regime of General Abdulsalami Abubakar (June 9, 1998 May 29, 1999), there was one woman from northern Nigeria in the Federal Executive Council: Dr. Laraba Gambo Abdullahi (Minister of Women Affairs). ${ }^{50}$ In the Fourth Republic which started on May 29, 1999, the Nigerian political terrain has witnessed an increase in the number of Muslim women political appointees and few women won elections councilors, chairpersons and senator but there is no female governor. ${ }^{51}$ In the National Assembly, for instance, there is only one Muslim woman from northern Nigeria, Hajiya Khairat Abdul-Razaq (now Hajiya Gwadabe) representing the Federal Capital Territory. ${ }^{52}$ There is also only one Muslim woman from northern Nigeria. She is Binta Garba. Women have been appointed as Commissioners and therefore members of the Executive Councils in some states in northern Nigeria. ${ }^{53}$ During this period, President Olusegun Obasanjo has appointed two Muslim women from northern Nigeria into the Federal Executive Council. They are Dr. (Mrs) Amina Ndalolo (Minister of State, Federal Ministry of Health), and Hajia Aishatu Ismaila (Minister of Women Affairs). Also, President Musa Yar"eAdua, in his short-lived administration, included Muslim women from northern Nigeria, namely, as Saudatu Bungudu and Salamatu Hussaini Suleiman in his cabinet. ${ }^{54}$ In 2011, President Jonathan appointed 33\% of women into political offices. They included

\footnotetext{
${ }^{46} \mathrm{Ibid}$.

$47 \mathrm{lbid}$.

${ }^{48} \mathrm{lbid}$.

49 lbid.

$50 \mathrm{lbid}$.

${ }^{51} \mathrm{lbid}$.

$52 \mathrm{lbid}$.

${ }^{53} \mathrm{lbid}$.

${ }^{54}$ Otu Ekpenyong 2015: 2.
} 
Muslim women from northern Nigeria who were Zainab Maina (Women Affairs), Prof. Ruqayyatu Rufai (Education), and (Finance), Zainab Ibrahim Kuchi (Niger Delta Affairs, State). ${ }^{55}$

Today, northern Nigerian Muslim women have encountered a number of problems while venturing into politics. This is as a result of large-scale marginalization both in voting exercises and in allocation of political offices. Political violence and the social stigma that politics is a dirty game is a further stumbling block for northern Nigerian Muslim women to become actively involved in the politics of this country. Another major cause for the low representation of northern Nigerian Muslim women in politics is the purdah system (i.e. house seclusion of women). ${ }^{56}$ Another problem facing northern Nigerian Muslim women is lack of adequate education. northern Nigerian Muslim women constitute a larger percentage of the illiterate group in Nigeria. Lack of adequate finance is a crucial hindrance to effective northern Nigerian Muslim women participation in politics in Nigeria.

\subsubsection{The Economic Role of Northern Muslim Women in Nigeria's Development}

The economic role of northern Nigerian Muslim women is guided by the economic behavior and conduct expected by the Islamic society. ${ }^{57}$ Even though, Nigerian Muslim women in northern Nigeria has been contributed to the economic growth of Nigeria. Northern Nigeria being predominantly an agricultural country, most of the people live in rural areas. ${ }^{58}$ Farming is the primary occupation that determines the rhythm of economic life. ${ }^{59}$ In such an environment people live modestly, dedicating themselves mostly to traditional occupation. In the precolonial period, for instance, Nigerian economy was basically at a subsistence level, and northern Nigerian Muslim women participated effectively in this economy. ${ }^{60}$ Apart from being mothers and wives and taking charge of the domestic sector, women contributed substantially to the production and distribution of goods and services. In the agricultural sector, the northern

\footnotetext{
55 Otu Ekpenyong 2015:2.

${ }^{56}$ Vivian Bakpa 2018; Otu Ekpenyong 2015:9.

${ }^{57}$ Fati Usman, (32 years), Maiduguri, interviewed on 02/04/2018.

58 Uwa Lohor 1998:39.

${ }^{59}$ Fati Usman, (32 years), Maiduguri, interviewed on 02/04/2018.

60 Ibid.
} 
Nigerian Muslim women farmed alongside their husbands and children. ${ }^{61}$ northern Nigerian Muslim women in pre-colonial Nigeria were fully involved in food processing, for example, fish drying (especially in the coastal areas. Women were engaged in pottery making. ${ }^{62}$ In fact, even the northern Nigerian Muslim women in purdah were involved in food processing and traded with the aid of their children. Most often, these northern Nigerian Muslim women supplied the means of sustenance for entire households.

Today, there are many constraints that face northern Nigerian Muslim women. The first of these constraints is access to land which has been dominated by men. ${ }^{63}$ Labor is a challenge to females because men have left rural economies in search of more viable livelihoods and northern Nigerian Muslim women have lost access to male help or the money they may have previously provided. For most women to increase their yields is through even harder work, using more labor-intensive methods.

These constraints face must be addressed for northern Nigerian Muslim women to fully develop their roles. ${ }^{64}$ Nigerian Muslim women should have the right and the freedom to choose their economic activities. They should also have the right of ownership and the right of management in various agricultural, industrial and technological fields. The objectives of economic activities for northern Nigerian Muslim women is to promote the standard of material and economic productivity along the line of political and cultural objectives of the Islamic society and system to ensure development of social justice and public welfare, and promotion of the standard of human culture, knowledge, morality and spirituality.

\subsubsection{The Intellectual Role of Muslim Women in National Development}

The presence of Muslim women in the arena of Knowledge and thought is also of almost important for the development of a fields of knowledge such as experimental sciences, industry, culture literature, mysticism, philosophy, theology and the Qur'anic knowledge. This knowledge will equip women to serve in different field. Therefore, for women to perform this great role in

\footnotetext{
${ }^{61} \mathrm{lbid}$.

$62 \mathrm{lbid}$.

${ }^{63} \mathrm{lbid}$.

${ }^{64}$ Tinuke M. Fapohunda 2012: 14.
} 
the academia or in public offices, women should strive to attain a level of education needed in Nigeria. Nana Asma'u, the daughter of Usman dan Fodio, was a prominent scholar and teacher who wrote many poems and religious tracts. She also organized a series of Qur'anic schools for women, and devised teaching programs that allowed women to participate in the schools while honoring their seclusion. ${ }^{65}$ Hence, the need for women to be educated and play their role well in nation building.

Today, in northern Nigeria, there are many women who are contributing toward the development of education in the region and Nigeria in general. For example, Aisha Lemu, who is an educationist and writer. She has been contributing to the establishment of several schools under the Islamic Educational Trust. She has written several Islamic books, all these within the short of twentieth six years when she accepted Islam. Her positive contribution in other areas of Islamic interest are too numerous to mention. ${ }^{66}$ The region has had also women professors. The good example is Zainab Alkali. She is regarded as the first woman novelist from Northern Nigeria. Some of her writings are: The Stillborn, Lagos: Longman (Drumbeats), 1984. The Virtuous Woman, Longman Nigeria, 1987. Cobwebs \& Other Stories, Lagos: Malthouse Press, 1997. The Descendants, Tamaza, 2005. The Initiates, $2007 .{ }^{67}$ There are also many northern Nigerian Muslim women as commissioners, education secretaries, supervisors and some are heading primary and post-primary institutions. Others are inspectors and directors of education, like Raliat Sanni who is another hardworking sister who has contributed immensely in the propagation of Islam through education. She is, by the blessings of Allah an educationist and of strong Islamic family. She was a director of Education in Kwara State and asset to the movement of women organizations in Nigeria.

\subsubsection{The Social Role of Muslim Women in National Development}

The true understanding of the social role of Muslim women in national development lies in the insight into the freedom of women and theoretical principles thereof and the areas of their freedom. The Muslim women have significant role in the socialization of social institutions like

\footnotetext{
${ }^{65}$ Kathleen Sheldon 2005: xi.

${ }^{66}$ Ahmed Badamasiyyu 1998:18

67 "Zainab Alkali” available at https://en.wikipedia.org/wiki/Zaynab Alkali accessed on 20.09.2018.
} 
marriage, child-bearing, upbringing and early education. ${ }^{6}$ However, failure to distinguish between the sexual role and the sexuality role of women, is a cultural barrier against the realization of women's role in national development. The sexual role involves the biological differences between men and women. ${ }^{69}$ The sexuality role is entrusted to women from social stand point i.e. children, which is a common role for men and women. Where trying to emphasis here is that the practical role of Muslim women in national development is the combination of the concepts of human development, social role, proportionate sexuality, social prosperity and development and participation in the process of development.

Today, Muslim women are assuming an increasingly important place in Nigeria, demonstrating their changing roles in the development of social sphere in the country. On the social setting, the northern Nigerian Muslim women interacted with one another freely provided the land was at peace. ${ }^{70}$ They engaged in almost all social activities with providing the major sources of entertainment during ceremonies, popularly known as "kalangu", "kidan kwarya" etc. ${ }^{71}$ The women also composed songs/folklores to entertain guest during social gatherings, including royal palaces. In addition to the human and social prestige and role at higher sociological levels, women have a multiple responsibility role in the family including the protection of human and religious nature of the family in their pivotal role. The role of Muslim women in the capacity of mother and wives never opposed their social, political economic or cultural activities in the society. Motherhood is an intrinsic role behavioral abnormality of a nation. The dual responsibility of Muslim women is to combine their great human divine role of motherhood and strong religious faith in the family, then society and finally a nation at large.

\subsubsection{The Role of Muslim Women in NGOS For National Development}

In the same vein, the serious integration and participation of Muslim women at national and international levels necessitates special means based on their effectiveness in the process of national development. In this aspect, the community based and non-governmental associations

\footnotetext{
68 Uzoma Aja-Okorie 2013:276.

${ }^{69}$ Fati Usman, (32 years), Maiduguri, interviewed on 02/04/2018.

70 Nana Auwalu, (34 years), Nguru, interviewed on 04/04/2018.

${ }^{71}$ Maryam Ibrahim, (45 years), Kano, interviewed on 11/03/2018.
} 
with the humanitarian and sublime objective of betterment, have been organized in different societies and nations. ${ }^{72}$ These establishments, in accordance with religious, national and cultural conditions, and in line with the needs and circumstances of their societies can play a significant role in national development o round it all, the true meaning of national development cannot be realized without mutual material and spiritual development. Stressing conventional indicators of national development can be considered a holistic approach to all-round development of a nation. It is the magnitude of these developments which that have over the years continued to attract the attention of northern Nigerian Muslim women engage themselves in community based and nongovernmental organizations. In northern Nigeria today, women have founded many organizations whose objectives are the achievement of equality, development and peaceful coexistence of Nigeria. Zara'u rightly said:

We women have rightly recognized the imperative danger that looms in any society which ignores the positive contributions of women in development. To correct these ills and to terminate discriminatory practices against women in all spheres of life, we deliberately formed our organizations. ${ }^{73}$

\subsubsection{The Cultural Role of Muslim Women in National Development}

The cultural role of Muslim women in national development is summed up in the morality, behavior conduct and ideal cultural norms of the Islamic society which should be defined and observed by noun. In this region, during this study and in the internal cultural structure of the society I find two components i.e. social values and morality. Thus, the cultural role of women is formed at higher sociological levels in relation to social thought and education and what is expected from women as far as morality and human values of demand which later transcends to national development. ${ }^{74}$

\subsection{Conclusion}

\footnotetext{
72 Hassana Bamadu, (46 years), Maiduguri, interviewed on 01/04/2018.

${ }^{73}$ Zara'u Hamisu, (48years), Abuja, interviewed on 02/03/2018.

${ }^{74}$ Sadiya Adamu, (31 years), Sokoto, interviewed on 10/03/2018.
} 
In Nigeria, Muslim women, they constitute more than half of the population of Nigeria, yet they are neglected to the background in the scheme of things. The widespread image of the oppressed, passive, and dependent Muslim women does not comply with most of the teaching of Islam observed by me. Nevertheless, it is observed that the social status of women is tightly knitted with the entire cultural of a society. The status of women is the result of historical processes and only explainable with that background in mind. Although economic and educational opportunities for women increased, the Nigerian Muslim community remained traditional in its social structure, worldview, and approach to interpersonal relations. The principles upon which the community operated did not change drastically, and the male power structure did not alter in either the private or the public domain. Thus, the position of women changed little within these spheres, despite the expansion of opportunities for women in education and economic life. Change was slow, evolutionary, and within the framework of traditional society. In seeking to connect Muslim women and national development, we suggest the need to explore streams of thought beyond the primitive role of Muslim women of being bearing of children, domestic works and petty trading and other roles. As evidenced above, Muslim women, if protected and given their right under Islamic law and Nigerian constitution, would rescued from many injustices existing in other areas such as social, political, economic, cultural, religious and legal systems. Emphasis here should be on Muslim scholars to give proper interpretation and implementation of the principles of shariah, particularly those regarding women. This will enable Muslim women to fully participate in national development. Therefore, yy recognizing the potential needs and re-affirming the roles of Muslim women is a key solution to cultural, social and economic crisis of contemporary Nigeria.

\subsection{Recommendations: The Way Forward}

Below are some recommendations for participation of northern Nigerian Muslim women in national development to thrive:

(1) Equality of women is necessary as a basic condition of social, economic, and political development of the nation; 
(2) Improvement of employment opportunities and earning power should be given the highest priority to release women from their dependent and unequal status;

(3) Society owes a special responsibility to women as mothers; safe bearing and rearing of children, therefore, is an obligation that must be shared by the mother, the father and the society.

(4) The contribution made by an active house-wife to the management of a family should be accepted as economically and socially productive and as essential for national savings and development;

(5) Marriage and motherhood should not become disabilities, preventing women from fulfilling their full and proper role in the task of national development for which society, including women themselves, must accept their due responsibilities;

(6) Disabilities and inequalities, of which women are victims, cannot be removed for women only: such action must form of a total movement for removal of all inequalities and oppressive social institutions;

(7) Some special temporary measures will be necessary to move in the direction of the goals set by the Constitution and to transform de jure equality into a de facto one.

\section{Reference}

\section{Primary sources}

Maryam Ibrahim, (45 years), Kano, interviewed on 11/03/2018.

Sadiya Adamu, (31 years), Sokoto, interviewed on 10/03/2018.

Zara'u Hamisu, (48years), Abuja, interviewed on 02/03/2018.

Hajiya Hauwa, (41 years), Nguru, interviewed on 24/03/2018.

Yani Garba, (28 years), Maiduguri, interviewed on 23/03/2018.

Umma Abdullahi, (23 years), Nguru, interviewed on 04/04/2018.

Nana Auwalu, (34 years), Nguru, interviewed on 04/04/2018.

Zainab Bukar, (40 years), Maiduguri, interviewed on 06/04/2018. 
Hassana Bamadu, (46 years), Maiduguri, interviewed on 01/04/2018.

Fati Usman, (32 years), Maiduguri, interviewed on 02/04/2018.

\section{Secondary sources}

Ahmed, Badamasiyu. "The Challenge of our Time". In ed. Rahmatu Abdullahi. The Muslim Woman: Challenges of the 15 th Hijra. Ilorin: Woye \& Sons (Nig.) Ltd., 1988.

Aja-Okorie, Uzoma. "Women Education in Nigeria: Problems and Implications for Family Role and Stability”. In European Scientific Journal. (October 2013), edition vol.9, No.28.

Attoe, S. A. Effah. "Women in the Development of Nigeria Since pre-colonial Times" Online Nigeria. 10 September 2002.

Ayesha, Imam. “Women's Liberation: Myth or Reality?”. In ed. Rahmatu Abdullahi. The Muslim Woman: Challenges of the 15 ${ }^{\text {th }}$ Hijra. Ilorin: Woye \& Sons (Nig.) Ltd., 1988.

Callaway, Barbara J. Muslim Hausa Women in Nigeria: Tradition and Change. New York: Syracuse University Press, 1987.

Christopher, Amherst Byuma Zigira. Religion, Culture and Gender: A Study of Women's Search for Gender Equality in Swaziland. Muenchen: LINCOM GmbH, 2003.

Fapohunda, Tinuke M. "Gender and Development: Challenges to Women Involvement in Nigeria's Development” In International Journal of Academic Research in Business and Social Sciences, (June 2012), Vol. 2, No. 6

Hassan, Salah M. Art and Islamic Literacy among the Hausa of Northern Nigeria. New York: The Edwin Mellen Press, 1992.

Kathleen, Sheldon. The A to Z of Women in Sub-Saharan Africa, Mayland: Scarecrow Press, Inc., 2005.

King, U. "Gender and the A Study of Religion". In King, U. ed. Religion and Gender (1-40). Oxford: Blackwell, 1995.

Lawal, T. and Oluwatoyin, A. (2011) National Development in Nigeria: Issues, Challenges and Prospects. Journal of Public Administration and Policy Research, 3, 237-241. 
Oto, Ekpenyong et'al. "Politics in Nigeria: To What Extent Has the Gender Agenda Gained Momentum?" in IOSR Journal of Humanities and Social Science (IOSR-JHSS) Volume 20, Issue 5, Ver. 1 (May. 2015), PP 01-10.

Uwa Lohor. "The Participation of Women in Politics and Development in Plateau State: A Practical Approach” in Ben Orewere et'al eds. The Plateau State Woman: Yesterday, Today \& Tomorrow. Jos: Ehindero (Nig.) Limited, 1998.

Vivian, Bakpa. "Challenges Nigerian Women Face In Politics". In the Pointer newspaper, September $17,2018$.

Zainab Alkali available at https://en.wikipedia.org/wiki/Zaynab_Alkali accessed on 20.09.2018. 